\title{
Religious Workers
}

National Cancer Institute

\section{Source}

National Cancer Institute. Religious Workers. NCI Thesaurus. Code C122503.

Clergy conduct religious worship and perform other spiritual functions associated with beliefs and practices of religious faith or denomination. They also provide spiritual and moral guidance and assistance to members. Directors of religious activities and education plan, direct, or coordinate programs designed to promote the religious education or activities of a denominational group. They may provide counseling and guidance relative to marital, health, financial, and religious problems. 